\title{
Gender Equality in Novel Cinta Suci Zahrana and Bidadari Bermata Bening by Habiburrahman El Shirazy
}

\author{
Thera Widyastuti \\ Department of Literature \\ Universitas Indonesia Depok, Indonesia \\ Syarif Hidayatullah State Islamic University Jakarta, Indonesia \\ therabega2002@yahoo.com
}

\begin{abstract}
The Qur'an recognizes anatomical differences between men and women. The Qur'an also recognizes that each gender function by reflecting on the differences that have been formulated well and maintained by the culture, both from women and men. Women have limited role in the domestic sphere, while men are more dominant in playing roles in the public sphere. Patriarchal society sees women as weak, emotional, subtle, and shy while men are strong, rational, abusive and brave. Novel of Cinta Suci Zahrana and Bidadari Bermata Bening by Habiburrahman El Shirazy presents the main character of beautiful and intelligent women who are religious. The problem in this research is how gender equality in the novel of Cinta Suci Zahrana and Bidadari Bermata Bening. The method used is qualitative with intrinsic approach (character and setting), and extrinsic (sociology of literature and feminism). Zahrana and Ayna are portrayed as independent female characters who can play a role in the public sphere. Their intelligence in education is able to make them equalize with men.
\end{abstract}

Keywords- intelligence; gender; Islam; independent

\section{INTRODUCTION}

In many countries, many woman suffer from the attitude of society, where women are placed in the domestic sphere. The emergence of feminist movement depends on the understanding that in all societies which divide the sexes into differing cultural, economic, or political spheres, women are less valued than men.

In the $1840^{\text {ec }} \mathrm{s}$ can be called a starting point in the history of feminism. Although there are already women who get a recognized position of society, feminism has not been too much developed at that time. Feminism is an historically diverse and culturally varied international movements. The Second Sex written by Simone de Beauvoir [1] argument that society sets up the male as a positive norm, and „woman ${ }^{\text {ee }}$ as the negative, second sex, or 'Other'. One is not born but rather becomes, a woman. Feminism evolves all over the world and fights for abortion and equal rights reform and acts prohibiting sexual discrimination. The Egyptian scholars who studied to Europe learned the feminist discourse that was widely spread in Europe, then it was "adopted" by them after returning from Europe to developed and known by the term "Tahrir alMar'ah" (liberation of women). This movement rapidly developed when people realized the oppression by women, caused by colonialism and modernism [2]

Along with the development of feminism, encountered different streams that led to a variety of feminism. Fakih argues that feminism is not an attempt to rebel against men, against social institutions such as domestic and marital institutions, and women's attempt to deny their nature, but an attempt to end women's oppression and exploitation, the feminist is a struggle in order to transform the system and the unjust social structure toward justice for women and men [3]. The practice of social life during the time of the Prophet was recognized to have placed the position of women in equal position with men.

The patriarchal of the ignorant period was dismantled by giving women rights which were not given in the past [4]. Patriarchal culture in society is reinforced by the emergence of various inventions and intellectual works that occurred in the golden age of Islam. Feminist Annete Baier argues that women in their moral contexts have a different will than men. Women are more concerned with meaningful ethical values for Their lives. Women live in societies where their feminine values are underestimated and unimportant, their entire existence as women subordinated [5].

A partial and literal understanding of society about the Qur'an and its hadith causes women to be marginalized in Muslim countries. A study of the normative propositions that have made gender inequality prevalent. The Qur'an seeks to eliminate the differences between men and women, or eliminates the importance of gender differences, so that gender inequality does not occur. The Qur'an does not teach discrimination between men and women as human beings. In the presence of Allah, men and women have the same degree, but the problem lies in the implementation of that teaching. The Qur'an in general and in many verses has spoken of gender relations, the relationship between men and women, their rights in a neat, beautiful and fair conception. The Qur'an that was revealed as a human guide, the conversation is not too far away with the circumstances and conditions of the environment and society at that time. As mentioned in QS. An-Nisa, that women as noble beings and must be respected, and Allah has equalized men and women as servants and creatures of Allah, who each if charity sholeh, would be given a reward in accordance with the charity. Both are created from one soul (nafsun wahidah), which implies that there is no difference between the two. Everything is under the supervision of Allah and has a duty to piety to Allah (ittaqu robbakum).

Based on the background, the research problem is how gender equality is described in the novels Cinta Suci Zahrana [6] and Bidadari Bermata Bening [7] by Habiburrahman El Shirazy, and the research objective is to identify the gender equality described in the novels Cinta Suci Zahrana and 
Bidadari Bermata Bening by Habiburrahman El Shirazy.

The author found other articles with similar problems with this research in the literature review process. Those theses, among others, are:

1. Moral analysis in novel Cinta Suci Zahrana by Habiburrahman El Shirazy. Vicky Choirul Abidin. 2013. According to him, the main character described as an intelegent and kind woman who always succeed to be an independent person.

2. Psychology of literarture and education value in novel Cinta Suci Zahrana by Habiburrahman El Shirazy. Viona Indhriasari. 2014. She found that female character bears the psychological burden of the suffering of her life.

\section{METHOD}

The method used in this research is the descriptive method of analysis. Meanwhile, using descriptive method to describe some facts or events, which are appear in the work. There are two approaches that are used in this research; intrinsic and extrinsic. The intrinsic approach was used to examine the existing elements and construct inner literary works (character and characterization, and setting), and the extrinsic approach was used to examine the external literary elements (sociology of literature and feminism) in analyzing the novels.

\section{A. Character and Characterization}

All stories must have certain characteristics. Without these elements, any piece of literature would cease to make sense or serve a purpose. Character can be defined as any person, animal, or figure represented in a literary work. A character is a fictional individual who experiences events or undergoes various events in the story [8]. A character must be displayed with a strong affinity, forming a unity of impression and understanding of the individual ${ }^{\text {ee }} s$ personality, so that the motivation or reason of the action performed by a character can be understood.

\section{B. Setting}

The setting of literature is the time and place in which the story takes place. The definition of setting can also include social statuses, weather, historical period, and details about immediate surroundings. Settings can be real or fictional, or a combination of both real and fictional elements.

\section{Sociology of Literature}

The sociology of literature proves very useful to understand the socio-economic situations, political issues, the world view and creativity of the writers, the system of the social and political organizations, the relations between certain thoughts and cultural configurations in which they occur and determinants of a literary work. Sociology of literature is a scientific approach that emphasizes on the objective analysis of people in society, social institutions, and social processes [9].

\section{Feminism}

Feminism is a movement aimed at transforming the position of women in society to gain equality with men. Feminism also, by its nature, embraces the belief that all people are entitled to freedom and liberty within reason including equal civil rights and that discrimination should not be made based on gender, sexual orientation, skin color, ethnicity, religion, culture, or lifestyle. Liberal feminism is a form of feminism that highlights the equality of rights for women to be accepted through legitimate ways and improvements in social affairs, and that the application of women's rights can be realized if women are equal with men [10].

Gender differs from sex. The notion of sex is the division of two biologically determined sexes attached to a particular gender. While the concept of gender that is a trait inherent in men and women who are socially and culturally constructed.

\section{RESULT AND DISCUSSION}

To analysis of gender equalities in these two novels uses intrinsic and extrinsic approaches. The focus in this research is the main character.

\section{A. Cinta Suci Zahrana}

\section{Character and Characterization}

The main character in this novel is Dewi Zahrana or commonly called Rana. A beautiful and intelligent single woman, but her age is over thirty years old.

\footnotetext{
"She's not young anymore. Thirty-four years. Friends of her age already have two, three, four, and even five". Her junior, even students who she guided their thesis have already married. (CSZ, p.165)
}

She lives in a modest house with her parents. Her father is an employee, named Munajat, and her mother is a house wife, named Nuriyah. They are a religious family, a moslem family. Zahrana was able to finish her education well.

Many achievement she got, including the smartest national student. Her name is known to many people in campus, by lecturers, students, and employees. (p.8)

She studies at Engineering Faculty higher education, and graduated from post graduate at Gadjah Mada University, Yogjakarta. She has many achievements and appreciation received as a student.

\section{Setting}

Zahrana came from descent family. Her parents live in a small house outside Semarang, Central Java, Indonesia. Her father has to pay installments to buy the house.

\footnotetext{
A small house on the edge of this Klipang Asri housing bought by her father in installments for years. A house full of history for her father and mother. They not possibly want to leave it. (p.23)
}

Semarang is a capital of Central Java which has many 
potential. There is a big port, and also canals like Venice, Italy. As a big city, many people live and work in Semarang.

\section{Feminism}

Zahrana has a dream to realize his dream of becoming an architect. After graduating from college, he worked as a lecturer at the Engineering Faculty, Mangunkarsa University in Semarang.

Life can be called adequecy. Have a respectable job, and can be proud of. She able to gain a master's degree in engineering from a prestigious technology institute in the country. And now he is trusted to occupy the permanent lecturers at a prominent private universist in the capital of Central Java province: Semarang. (p.162)

She becomes an independent woman with a very proud achievement. She derives an honor for her work as an architect from a leading university in Beijing.

The host on television shows to the audience that there is one of the nation's proud achievements, a young architect from Semarang who won a prestigious award from a leading university in Beijing. (p.66)

Zahrana's achievements show that women are capable of equal ability with men. She performed a public role as an architect and lecturer. The feminist spirit that appears to be showing in this way how 'ordinary' women become 'extraordinary'. Zahrana's intelligence becomes a 'weapon' for the second success in the public sphere. In this novel, the female character is depicted as having the ability to fight against the injustices that happened to her.

Zahrana's age should be married, and having children. Therefore, both parents of Zahrana want their child to marry soon. They had impeled her to get married with a respected person.

"Your father and mother are uncomfortable to hear that you are being gossiped as a spinster. Make us proud that you are married to a respected person, so our waiting is not in vain", said Mr. Munajat rather harshly (p.162)

Marriage becomes a bridge for women to enter the domestic sphere where as a wife has to do her duties and obligations. But the work in the domestic sphere does not get public awards. Woman is considered a "second sex". Although there are men who do domestic work, it remains socially unappreciated because this work is considered a 'women's job'. That women's work is considered inferior, on the contrary the work of men is respected. Because women mostly work on domestic, the evaluation of women's work affects the evaluation of women's existence as an individual [11].

As a single, Zahrana is open to anyone's liking. Sukarman, dean of the Engineering Faculty, Mangunkarsa University loves her without thinking of Zahrana's feelings. He insisted his will to have Zahrana to be his. His position as dean used to fulfill his desire.

The happiest moment when he will marry a girl who he sure would not dare to refuse his proposal. Amazingly by marrying the girl, her honor will be increasingly raised. Because the girl is not an ordinary girl. She is Dewi Zahrana, the most accomplished lecturer in his faculty (p.122)

Male and female predicates are considered status symbols. Men are identified as people who have the characteristics of masculinity, while women are identified as people who have characteristics femininity. The dominance of men in society is not just because they are male, but because they have much access to power to gain status. According to Mary Wollstonecraft, women are a human personhood- as a whole. Not just "tools or instruments" for the happiness or perfection of others. By contrast, women are a "goal" whose pride exists in its ability to determine her own destiny [12]. Treating a person as a tool is just like treating the person as non-human, as someone who exists not for herself, but as a tool for others.

\section{B. Bidadari Bermata Bening}

\section{Character and Characterization}

This novel featured the main character of a girl named Ayna Mardeya binti Abdullah Jalal or commonly called Ayna. She is eighteen years old when graduated from MTs Kanzul Ulum in Magelang. Both her parents were died when she was small.

She is a great santri. Orphan. Her father died since she in the womb of her mother. In pesantren, she was carrying a heavier job than her friends. She is a khadimah. By Allah, every work that is burdened to her, is completed thoroughly. She will not give up until her mandate is fulfilled. Despite such a burden, she managed to write down the magnificent history of pesantren. When she was given time to focus on learning when facing the national final exam, she was able to score achievements that had never been gained before in pesantren. (BBB, p.69-70)

She is described as a smart girl and managed to achieve the highest score in her school when the national final exam. Various prizes received for her achievements.

\section{Setting}

Ayna ${ }^{e e}$ s hometown is located west of Purwodadi, Central Java where his mother's house still stood beside the pakde Darsun $^{\text {ee }}$ s house. He is a younger brother of Ayna ${ }^{\text {ee }}$ s mother.

From Terboyo terminal, she took a small bus to Penggarong, east of Semarang. From Penggarong take the Purwodadi bus and get off at the Gubug. From Gubug ride motorcycles to the village of her birth, village of Kaliwenang which entered the district Tanggungharjo, Grobogan. (p.96-97)

Purwodadi is a quite small city in central Java, not many economic activities has done in that city. Its almost three hours drive from Purwodadi to Magelang.

That pesantren can be called as one of the old pesantren in magelang. Located on the edge of Secang. Precisely in the village of Candi Retno. (p.39)

Ayna live in Magelang in pesantren Kanzul Ulum at Candiretno, Magelang. It is located between Mount Merbabu 
and Mount Sumbing in Central Java Province, Indonesia.

\section{Feminism}

Allah creates men to worship Allah. In the capacity of men as servants, there is no difference between men and women, both have the same potential and opportunity to be ideal servants. They had opportunity of equal education for women and men. Education must be owned by all levels of society. Capitalize the good achievement gave birth to the opportunity to gain a better life. Islam requires its people to study and not to distinguish between women and men.

"This is no less important, Mr. Bupati also gave present for Ayna Mardeya binti Abdullah Jalal, for achieving the highest on National Test score in Central Java and in the top ten nationally that has scented Magelang". (p.66)

The result of Ayna's hard work gave the opportunity to manage a pesantren named Bait Ibni Sabil. With staff, she teaches the students to reciting the Quran correctly. Besides, she also established a bakery factory 'Barokah "which is peddled around the village. Ayna is able to lead her employees well and make her a respected leader.

The relationship between women and men who are bound in a marriage is a worship prescribed by islam. Marriage has a purpose to expect the blessings of Allah. Marriage that occurred between Ayna and Yoyok did not give her happiness. Her husband wants to sell Ayna to an elderly lawyer so that he can be free of lawsuits.

He called Mr. Brams Margojaduk, S.H., and he can arrange everything. At dinner it turns out he's attracted to you. Or the language of young generation, falling in love with you. He told many stories to our informant. He will help us through our informant. If Yoyok wants to release you, then you are willing to be his wife. Then we will all be saved. (p.213)

Ayna is treated as an object and makes herself treated unfit to her status as a whole person. Wollstonecraft argues that no woman should allow such violence to be committed against her. Finally, Ayna divorced from her husband. She choose to remove all relationships from her husband and family. In patriarchal society, the whole universe of rules applies to the "male rule" system, the selfishness which centers on the will of men so that the public world becomes male domination [13].

\section{CONCLUSION}

Islam has taught gender equality and justice. But because of a deeply rooted patriarchal culture, it is supported by a lack of understanding of the verses in the Qur'an as well as the hadiths that interpreters tend to marginalize women so that women are still at a disadvantage.

In Cinta Suci Zahrana, the main character is featured as a smart, yet unmarried woman. Achievements and awards she achieved that indicates that her presence as an independent woman equivalent to men in the public sphere. While in Bidadari Bermata Bening, where Ayna figure as khadimah who has extraordinary intelligence, so she carved history in pesantren as the first santri with the acquisition of almost perfect score. Her success shows that women are able to achieve achievement in education equivalent to men. In the patriarchal society, both Zahrana and Ayna are able to appear as a personhood, intact as themselves. They work hard in order to gain the confidence to do positive things so that people reward their work. Women have the ability to work in the domestic and public sphere. Women are able to do many things; for themselves and also for the family.

\section{REFERENCES}

[1] de Beauvoir, Simon. The Second Sex. 1949. https://www.free-ebooks.net/ebook/The- Second-Sex.[Online]. [Accessed: 24-Oct- 2017].

[2] Hasyim, Syafiq dkk. "Gerakan Perempuan dalam Islam: Perspektif Kesejarahan Kontemporer", Majalah Tashwirul Afkar No. 05 p. 22$11,1999$.

[3] Sugihastuti and Suhartono. Kritik Sastra Feminis. Yogjakarta : Pustaka Pelajar, 2010.

[4] Asghar, Ali. Hak-Hak Perempuan dalam Islam (terj. Farid Wajidi dan Cicik). Yogjakarta : LSPPA, 1994.

[5] Baeir, Annete. Postures of the Mind: Essays on Mind and Morals. Minneapolis: University of Minnesota Press, 1985.

[6] Shirazy, Habiburrahman El. Cinta Suci Zahrana. Jakarta : Republika, 2017.

[7] Shirazy, Habiburrahman El. Bidadari Bermata Bening. Jakarta : Republika, 2017.

[8] Sudjiman, Panuti. Memahami Cerita Rekaan. Jakarta : Pustaka Jaya, 1988.

[9] Swingewood, Alan. Sociology of Literature. Michigan: Michigan University. 1972.

[10] Tong, Rosemarie Putnam. Feminis Thought. Yogyakarta: Jalasutra. 2008.

[11] Arivia, Gadis. Feminisme : Sebuah Kata Hati. Jakarta: Kompas. 2006.

[12] Tong, Rosemarie Putnam. (2008). Feminis Thought. Yogyakarta: Jalasutra, 2008.

[13] Arivia, Gadis. (2006). Feminisme: Sebuah Kata Hati. Jakarta : Kompas, 2006. 